\title{
12 Diaries of Solidarity in the Global Cold War: The East German Friendship Brigades and their Experience in 'Modernizing' Angola'
}

Solidarisch eng verbunden mit Angola das geschunden

Stolz erhoben dieses Land Kämpfen mit Ihm Hand in Hand ${ }^{2}$ Wir zogen an, das ist schon wahr Ersatzteile aber blieben stets rar! Drum war Erfindergeist gefragt Und jeder brachte uns 'ne Tat ${ }^{3}$

In solidarity closely connected with Angola sorely tormented this proudly risen land with whom we fight hand in hand

We held fast, that is true for sure but in spare parts we remained ever poor inventive spirits were in demand and everyone gave us a hand.

\section{Introduction}

In his monthly poems, Rudi reflected on the routines of his deployment in a Brigade der Freundschaft (also called Freundschaftsbrigade, "Friendship Brigade") in Angola. These collectives of young citizens of the German Democratic Republic (GDR) were sent to the "newly independent nation states" of the post-colonial world in order to enact the "international solidarity" that the GDR leadership

1 I am very grateful to the editors of this piece, Eric Burton and Immanuel R. Harisch, who made all the necessary and extremely helpful editorial suggestions. What is more, both were so kind to share their great expertise gained from working on the otherwise little-studied Freundschaftsbrigaden themselves.

2 “Gedanken,” Rudi S., April 1984, Stiftung Archiv der Parteien und Massenorganisationen der DDR im Bundesarchiv (hereafter SAPMO-BArch), DY 24/19129.

3 “Freude," Rudi S., February 1984, SAPMO-BArch, DY 24/19129. 
proclaimed as one of its basic political principles. The Brigaden of the GDR's official youth organization Freie Deutsche Jugend (FDJ, “Free German Youth”) provided social services or training and supported local economies by directly engaging in agriculture, transport, or construction. ${ }^{4}$

Rudi's poem echoed official solidarity discourses-namely as a unified struggle of African and German actors-but also reflected the practical dilemmas of exercising solidarity in Angola. Taking up this lead, my contribution seeks to reconsider the roles of young East Germans in the Freundschaftsbrigaden within the Cold War-which became a "hot war" in the vast and resource-rich country of Angola. ${ }^{5}$ My central aim is to examine the perspectives that the brigade collectives assumed and presented of their deployment to socialist Angola in the last decade of the GDR's existence. Particular attention is put on their views of the mission of "friendship" and "international solidarity" within their work environment and (official) encounters with the Angolan youth and project partners.

The discussion on the impact of official state solidarity and its ramifications in reality for this specific group of East German actors is inspired by Odd Arne Westad's emphasis on the importance of the interventionist and modernist polit-

4 This contribution relies on the solid basis of Immanuel R. Harisch's research on the deployment of the GDR's Freundschaftsbrigaden in Angola in the larger context of economic relations between the two countries. Apart from a general overview of the numbers, Harisch touches upon the issues of motivation, choice, and selection of the Brigadisten, the bilateral negotiations preparing their deployment, their remuneration as well as supply, provisioning, and accommodation, but also the fields, places, and results of their work, as well as instances of disciplining, racism, and corruption; Immanuel R. Harisch, "Handel und Solidarität: Die Beziehungen der DDR mit Angola und São Tomé und Príncipe unter besonderer Berücksichtigung des Austauschs 'Ware-gegen-Ware' ca. 1975-1990” (M.A. thesis, Universität Wien, 2018), 111-169. Ulrike Gödeke's study of the political organization of Freundschaftsbrigaden in Africa is equally very helpful to come to an overview of their role in the political context of the GDR; Ulrike Gödeke, "Zwischen brüderlicher Hilfe und allseitiger Stärkung der DDR: Die Freundschaftsbrigaden der FDJ in Afrika 1964 bis 1990” (Diploma thesis, Freie Unversität Berlin, 2002). While the scholarly literature on the Brigaden is generally scarce, Eric Burton has recently highlighted the entanglements of the brigades' activities with state interests as well as work relations and personal motives in his contribution "Solidarität und ihre Grenzen: Die Brigaden der Freundschaft der DDR," in Internationale Solidarität: Globales Engagement in der Bundesrepublik und der DDR, ed. Frank Bösch, Caroline Moine, and Stefanie Senger (Göttingen: Wallstein Verlag, 2018). For an apologetic account that still gives a good overview, see Ulrich van der Heyden, "FDJ-Brigaden der Freundschaft aus der DDR - die Peace Corps des Ostens?,” in Die eine Welt schaffen: Praktiken von 'Internationaler Solidarität, und 'Internationaler Entwicklung,' ed. Berthold Unfried and Eva Himmelstoss (Leipzig: Akademische Verlagsanstalt, 2012).

5 Vladimir Shubin, The Hot 'Cold War': The USSR in Southern Africa (London: Pluto Press, 2008). 
ical ideologies on both sides of the bloc divide for perpetuating the global Cold War. ${ }^{6}$ Westad states that "injustice and oppression became more visible in the $20^{\text {th }}$ century ... [and] people-especially young people-felt the need to remedy these ills. Cold War ideologies offered immediate solutions to complex problems."7 The commitment of the young East Germans within the context of the "anti-imperialist struggle" of Angola turns this group of actors into a relevant test case for Westad's assumptions. The Freundschaftsbrigaden were directly and personally affected by the global Cold War. Still, they have been mostly neglected in the existing literature on the GDR's international solidarity as well as in the literature on Angola's Cold War more generally.

The GDR's official and state party documentation indicates the interlinkages and entanglements of the Freundschaftsbrigaden's deployment in Angola with profane economic interests. ${ }^{8}$ In retrospect, this view is also shared by former brigade members dismissing the GDR's solidarity as "plundering among friends." Other memory accounts of brigade members rather stress apolitical understandings of an "adventurist journey."10

My approach, focusing on the contemporary motivations and their discussion in the Freundschaftsbrigaden, complements these views of former brigade members as well as recent scholarship. ${ }^{11}$ The analysis focusses on the Brigadetagebücher, annual "brigade diaries" that were written and compiled by the col-

6 Odd Arne Westad, The Global Cold War: Third World Interventions and the Making of Our Times (Cambridge: Cambridge University Press, 2005), 4-5; 39-73.

7 Odd Arne Westad, “The Cold War and America's Delusion of Victory," New York Times, August 28, 2017, accessed January 20, 2020, https://www.nytimes.com/2017/08/28/opinion/coldwar-american-soviet-victory.html. Apart from Westad, other historians, such as David Engerman or Sara Lorenzini, have also offered reflections on the links between "developmentalist" and Cold War ideologies. David Engerman, "Development Politics and the Cold War," Diplomatic History 41 (2017); Sara Lorenzini, Global Development: A Cold War History (Princeton: Princeton University Press, 2019).

8 Albrecht to Günter Mittag, “Abkommen über den weiteren Einsatz von FDJ-Brigaden,” February 12, 1981, 103, SAPMO-BArch, DY 3023/1464.

9 “Franke," “Mein Angola 1984," Angola Forum, accessed January 20, 2020, http://www.angolaforum.de/thread.php?board=3\&thread=1.

10 "Mit einer FDJ-Freundschaftsbrigade in Angola," MDR.de, January 13, 2011, accessed January 20, 2020, https://www.mdr.de/damals/archiv/artikel105354.html. For an exemplary analysis of not only East German but also Lusophone African (in this case Mozambican) memories of cooperation, see Piepiorka and Buanaissa, this volume.

11 Here I follow the suggestions of Berthold Unfried, "Instrumente und Praktiken von 'Solidarität' Ost und 'Entwicklungshilfe' West: Blickpunkt auf das entsandte Personal,” in Die eine Welt schaffen. Praktiken von 'Internationaler Solidarität, und 'Internationaler Entwicklung,' ed. Berthold Unfried and Eva Himmelstoss (Leipzig: Akademische Verlagsanstalt, 2012), 77. 
lectives themselves. These diaries were in line with similar documentation of economic and political collectives in the GDR. ${ }^{12 .}$ In the diaries, brigade members dutifully chronicled their deployment but also engaged in broader reflections. ${ }^{13}$ The entries in these diaries give insight into a dense network of official socialist encounters with Angolan counterparts of the socialist ruling party Movimento Popular de Libertação de Angola (MPLA) or the brigades' counterparts of the MPLA's official youth organization, the Juventude (JMPLA). Consequently, the Brigadetagebücher are unique and compact sources offering insights into concrete practices shaped by non-elite East German conceptions of international solidarity. They showcase the subjectivities of Brigadisten as well as the possibilities of their communication within the forum of the collective. Their perspectives were constrained by the expected audience, balancing different communicative demands. The "semi-official" diaries were part of the competition for collective awards and thereby favored entries by individual brigade members situating their mission within publicly condoned narratives. ${ }^{14}$

As I show in this contribution, the image of Angolans within the Tagebücher largely remained confined to the GDR's official framework of solidarity. The brigade members' mediated and fragmentary perspective on the Angolan counterparts presents the latter as willing and thankful beneficiaries of East German actions rather than complex individuals or even political allies. The Tagebücher only rarely give proof of direct repercussions that encounters with Angolans had for Brigadisten or point to potential criticisms against GDR policies emerging from the ruptures in their experiences. These limitations are due to the character of the sources as well as the rigidly controlled structured realities of the Brigaden's deployment.

Still, a close reading of the Brigadetagebücher can reveal how the dichotomy between the "modern" GDR and the "backwardness" of post-colonial Angola turned into a central interpretative frame for individual brigade members. The

12 Emerging out of the East German brigade movement of work collectives, brigade diaries were promoted as chronicles of collective work life to take account of participation in work competitions. See Jörg Roesler, "Berichtsbuch, Beschwerdeschrift oder Bilderfolge? Unterschiedliche Vorstellungen zum Inhalt von Brigadetagebüchern in den Anfangstagen der 'sozialistischen Kollektive,"” in Vorwärts und nichts vergessen. Sprache in der DDR - was war, was ist, was bleibt, ed. Ruth Reiher and Antje Baumann (Berlin: Aufbau, 2004).

13 For a broader introduction to the Brigadetagebücher as sources, see Immanuel R. Harisch and Eric Burton, "Sozialistische Globalisierung. Tagebücher der DDR-Freundschaftsbrigaden in Afrika, Asien und Lateinamerika," unpublished manuscript, forthcoming in Zeithistorische Forschungen.

14 The Brigadetagebücher were read and assessed by superiors. See Harisch and Burton, "Sozialistische Globalisierung.” 
task of "modernization" was understood as the fundamental transformation of the Angolan society by mirroring attributes that the East German actors assumed to be central for the basic set-up of their own society, such as rationalism and industrialization. ${ }^{15}$

I argue that the Brigadisten presented their deployment as a crucial factor in contributing to Angola's "modernization" along socialist lines through the transfer of knowledge and values. In practice, the Brigadisten strongly focused on their immediate surroundings as well as their concrete possibilities to this contribution and providing "humanitarian" relief as their main objectives. These practical concerns frequently contradicted the official GDR's cliché phrases of internationalism and anti-imperialism.

My findings therefore relativize arguments which stress the immediate centrality of socialist ideology for this group of exposed East Germans in the Cold War. Still, they also underline the emphasis in Odd Arne Westad's writing on the "modernizing" mission as a central dimension of Cold War ideologies with respect to nation building in countries such as socialist Angola. Remarkably, the members of the friendship brigades in Angola rarely engaged explicitly with the need for socialism. Instead of projecting a "politicized" understanding of their activities, I show how their "interventionism" focused on tangible practices of aid and the mechanics of modernization instead.

The tensions between the collectivist and individualist perspectives within these sources show how far the collectivist ideal within the brigades actually extended and how visions of solidarity were sourced between individual emphases and common proclamations. Not least, this collective source undermines common tropes contrasting African collectivism with European individualism, as a European collectivism comes into view. The taken micro-historical approach of a close focus on the brigades helps to trace the intensity and ambiguities of the brigades' socialist encounters, but also the extent of their (dis)entanglement with the political conditions in Angola as the Brigaden moored in this crucial locale of the Global Cold War.

15 This take on 'modernization' draws from Frederick Cooper, Colonialism in Question: Theory, Knowledge, History (Berkeley: University of California Press, 2005), 113, 120-122. 


\section{International Solidarity in the GDR's Global Cold War}

The Brigaden der Freundschaft and its members were active within the wider context of the GDR's foreign policy's focus on the "newly independent nation states" of the post-colonial world. Throughout the GDR's existence, the involvement with these countries was presented as international solidarity which even carried constitutional weight from 1974. ${ }^{16}$ The GDR would stand "united" with these states in a joint struggle against "imperialism" and "capitalism." ${ }^{17}$ Conceptually, international solidarity was presented as a quasi-natural life praxis of "true" and "mutual" friendship on an equal footing in no need of profound theoretical deliberations. ${ }^{18}$

In the GDR public sphere, officially condoned solidarity was legitimized and popularized by the state-socialist organizations from state-coordinated media to education. International solidarity was present(ed) as an ideological argument for the continued benefits of the East German political order despite the GDR's lethargic state. ${ }^{19}$ At the same time, non-state actors promoted values of international solidarity as well, but were marginalized by the official GDR. ${ }^{20}$ The "omnipresence" of this "mission" instilled it as an integral part of the political consciousness of GDR citizens.

With regards to the discursive functions of international solidarity within the GDR, Gregory Witkowski argues that the campaign for solidarity was supposed to mobilize East Germans into action by stressing the dependency of its recipients but also calling for a change of consciousness among GDR citizens. The predominant narrative of the already socialist East German state seeking to spread this remedy for continuing political ills was to position the GDR society "on the

16 “Artikel 6,"Verfassung der Deutschen Demokratischen Republik, October 7, 1974, accessed January 6, 2020, http://www.documentarchiv.de/ddr/verfddr.html.

17 Hans-Joachim Spanger and Lothar Brock, Die beiden deutschen Staaten in der Dritten Welt: Die Entwicklungspolitik der DDR - eine Herausforderung für die Bundesrepublik Deutschland? (Opladen: Westdeutscher Verlag, 1987), 39-49.

18 Hubertus Büschel, Hilfe zur Selbsthilfe: Deutsche Entwicklungsarbeit in Afrika 1960-1975 (Frankfurt: Campus, 2014), 77-78.

19 Ulrich Mählert and Gerd-Rüdiger Stephan, Blaue Hemden - Rote Fahnen: Die Geschichte der Freien Deutschen Jugend (Opladen: Leske und Budrich, 1996), 187-188.

20 Maria Magdalena Verburg, Ostdeutsche Dritte-Welt-Gruppen vor und nach 1989/90 (Göttingen: V\&R unipress, 2012). 
side of moral righteousness, ${ }^{21}$ and perpetuated a hierarchical and even racialized worldview. ${ }^{22}$

Toni Weis equally stresses the importance of the anti-colonial imaginary of solidarity and describes it as a vague ethic at the same time. ${ }^{23}$ Weis rejects discussions about its imposition or genuineness, underlining how solidarity was endorsed "to different degrees and for a variety of reasons." 24 Indeed, GDR citizens fundamentally agreed with the benevolence of East German support for anti-imperialist, anti-colonialist, and anti-capitalist causes, that could, at the same time, be acknowledged as genuine and state-imposed.

Exploring the reasons for the perpetual stability of the discourse, Weis introduces the picture of a "working misunderstanding" in the political relations of East German and African actors: the "rhetoric of solidarity remained abstract enough to be filled with different contents by the two partners and used for their own respective agendas." 25 With regards to the discourse within the GDR, Weis assesses how "[t]he image of the 'other' was confined to the framework of solidarity, which in turn reflected back-ideally in a positive way-on the GDR itself."26

\section{FDJ-Friendship Brigades in Socialist Angola}

By exploring the Freundschaftsbrigaden, set up in 1963 as a main actor of the GDR's practice of international solidarity, it is possible to reconsider the concrete implications of the solidarity framework. As tools of their foreign policy, detached to over 20 countries on three continents in total, the Brigaden were used by the SED leadership to woo "newly independent nation states" and their socialist alignment. ${ }^{27}$ From the mid-1970s onwards, the Freundschaftsbrigaden had a strong focus on Ethiopia, Mozambique, and particularly Angola as "socialist-ori-

21 Gregory Witkowski, "Between Fighters and Beggars: Socialist Philanthropy and the Imagery of Solidarity in East Germany," in Comrades of Color: East Germany in the Cold War World, ed. Quinn Slobodian (New York: Berghahn, 2014), 76.

22 Witkowski, "Between Fighters and Beggars," 88-89.

23 Toni Weis, "The Politics Machine: On the Concept of 'Solidarity' in East German Support for SWAPO," Journal of Southern African Studies 37 (2011): 352.

24 Weis, "Politics Machine," 359.

25 Weis, "Politics Machine," 352.

26 Weis, "Politics Machine," 363-364.

27 Ulrike Gödeke, “Zwischen brüderlicher Hilfe und allseitiger Stärkung der DDR.” 
ented countries."28 Their deployment was entangled with trade and export interests as well as it was linked to "solidarity efforts," such as the support of vocational training and donations organized by societal organizations of the GDR. ${ }^{29}$ In these countries, the alignment with the socialist bloc remained fragile and at times contested so that the East German employment of brigades served to continuously underline the benefits of cooperating with the GDR as a comparatively weak socialist economic and political partner.

The Freundschaftsbrigaden were joined by young men and (fewer) women of different professions who lived and worked as "collectives" in their countries of deployment. Before they traveled abroad, the brigade members were thoroughly checked for their political reliability and underwent training. Whereas the services of the Brigaden were usually provided free of charge, the host government was responsible for food and accommodation. ${ }^{30}$

In 1989, the FDJ celebrated the Freundschaftsbrigaden's mission to overcome colonial legacies and their role as the "bridges of friendship" to the youth of the postcolonial world. ${ }^{31}$ The FDJ named the provision of (vocational) training and possibilities for academic study as well as contributions to construction projects, or their work in industry, transport, and agriculture, as central objectives of the Freundschaftsbrigaden. Transport and agriculture were of particular importance to the activities of the Freundschaftsbrigaden in Angola. ${ }^{32}$ The GDR had emerged as a trusted partner among other socialist states for the ruling Marxist MPLA since at least the early $1960 \mathrm{~s}^{33}$ Its international relations to socialist countries were of vital importance to the MPLA to seize government control after Angolan

28 For a detailed list of the dispatched brigades from 1964 to 1989 see Ilona Schleicher, "Elemente entwicklungspolitischer Zusammenarbeit in der Tätigkeit von FDGB und FDJ," in Entwicklungspolitische Zusammenarbeit in der Bundesrepublik Deutschland und der DDR, ed. Hans-Jörg Bücking (Berlin: Duncker \& Humblot, 1998), 136-137.

29 Burton, "Die Grenzen der Solidarität," 157-161.

30 Immanuel R. Harisch, "Bartering Coffee, Cocoa and W50 Trucks: The Trade Relationships of the GDR, Angola and São Tomé in a Comparative Perspective," Global Histories 3 (2017): 44. 31 Zentralkomitee der FDJ, "25 Jahre Brigaden der Freundschaft - Berlin 28. Juli 1989," SAPMOBArch, DY 24/19631.

32 For a thorough account of the Freundschaftschaftsbrigaden's actitivities in Angola see Immanuel R. Harisch, "East German Friendship-Brigades and Specialists in Angola: A Socialist Globalization Project in the Global Cold War," in Transregional Connections in the History of East Central Europe, ed. Katja Naumann (Berlin: De Gruyter, forthcoming 2021).

33 Zentralkomitee der Sozialistischen Einheitspartei Deutschlands - Abteilung Internationale Verbindungen, “Angola,” 95-191, SAPMO-BArch, DY 30/98121. See also Hans-Georg Schleicher, "The German Democratic Republic (GDR) in the Liberation Struggle of Southern Africa," in Southern African Liberation Struggles 1960-1994: Contemporaneous Documents, ed. Arnold Temu and Joel das Neves Tembe (Dar es Salaam: Mkuki na Nyota, 2014). 
independence from Portugal in 1975 with the help of Cuban soldiers and Soviet arms. $^{34}$

Both should remain vital for the MPLA's hold to power with the continuation of Angola's anti-colonial liberation war as an internationalized civil war. The MPLA leadership's rule over the country was challenged by internal opposition within the party resulting in an attempted coup d'état in May 1977 and the continuing onslaught by competing former liberation movements. The interests of these armed groups were interwoven with those of neighboring states, such as Zaire, as well as South Africa which had control of Namibia. The dynamics of the Cold War, but also commercial interests in Angola's diamond and most importantly oil resources, guaranteed the longevity of conflict. ${ }^{35}$

Over the years following independence, the GDR leadership took strong interest in its political as well as economic relations with Angola. Seeing Angola as a model for other African states, an official of the East German Ministry of Foreign Affairs noted accordingly: "For the first time, a developing country with the foundations of a modern economy is on our side." ${ }^{36}$ Angola became not only a major and politically relevant supplier of coffee, but also an important export destination for GDR machinery and technologies, most notably the IFA W50 trucks. $^{37}$

The deployment of GDR personnel to Angola as technical and administrative experts as well as political advisers was an integral part of trade and cooperation. ${ }^{38}$ In late 1977, these GDR experts were joined by over 130 members of the

34 For an overview of Angola's history before and after independence see David Birmingham, "Angola," in A History of Postcolonial Lusophone Africa, ed. Patrick Chabal (London: Hurst, 2002).

35 For an overview of the longer-term entanglements of these interests, see Birmingham, "Angola," 155-179. For Cuba's paramount importance in the support of the MPLA government stressing a course of action independent from the Soviet Union, see Piero Gleijeses, Visions of Freedom: Havana, Washington, Pretoria and the Struggle for Southern Africa (Chapel Hill: The University of North Carolina Press, 2013). Gleijeses' further argument of Cuban "revolutionary idealism" stands in contrast to Christine Hatzky's who has pitted the importance of economic motivations for the lasting service of Cuban experts in Angola. Christine Hatzky, Cubans in Angola: South-South Cooperation and Transfer of Knowledge, 1976-1991 (Madison: University of Wisconsin Press, 2015), 181-188. For an account of the Soviet Union's role in this context, see Shubin, The Hot Cold War, 67-115.

36 Generalsekretär des Ministeriums für Auswärtige Angelegenheiten, A. B. Neumann, "Information über die Reise einer Delegation des MfAA in die Volksrepublik Angola," September 1, 1977, SAPMO-BArch, DY 3023/1463.

37 Harisch, "Coffee, Cocoa, and W50 Trucks."

38 Alexander Schalck to Günter Mittag, "Informationen über Aufenthalt Klaus Häntzschel, 5.14.10.1983 in Angola," SAPMO-BArch, DY 3023/1464. 
Freundschaftsbrigaden on the explicit request of the Angolan President Agostinho Neto who had himself once lived next to a brigade in his Tanzanian exile. ${ }^{39}$ The Brigaden were to mainly facilitate and guarantee the servicing of W50 trucks and coffee exports, mostly by familiarizing Angolans with (the repair of) the trucks as well as maintaining other agricultural machinery. ${ }^{40}$ Internal sources explicitly refer to such tasks as "Kundendienst," customer service, a term reflecting the brigades' integration into economic supply lines and inclusion into trade relations overall. ${ }^{41}$

The MPLA's youth organization, the Juventude do Movimento Popular de Libertação de Angola (JMPLA), was the direct counterpart of the FDJ in the deployment of the Freundschaftsbrigaden, an awkward fit as the JMPLA was a tiny cadre organization by comparison. ${ }^{42}$ Apart from their frequent exchanges with the JMPLA, the brigades also cooperated with other official organizations of the Angolan socialist society, such as the women's organization and the trade unions, but also the armed forces, most notably the regular army Forças Armadas Populares de Libertação de Angola (FAPLA). ${ }^{43}$ The East Germans were one group in a lively sphere of "internationalists" from the Soviet Union, Bulgaria, Vietnam, and Cuba among others-fertile ground for "socialist encounters".

The Brigaden of around 10 to 20 Germans were first based in the urban centers Luanda, Gabela, N’Dalatando, and Uíge. In later years, further Brigaden set up "repair stations" for GDR machinery and vehicles. From the beginning, the conditions of their service were plagued with problems, leading to dissatisfaction among the Brigadisten, but also fueling political dispute between the Ger-

39 A.B. Neumann, "Information über die Reise," 34, SAPMO-BArch, DY 3023/1463.

40 Harisch, "East German Friendship-Brigades and Specialists in Angola."

41 Erich Honecker to Günter Mittag, "Informationen über beendete Beratungen des Gemeinsamen Wirtschaftsausschusses DDR/VRA Angola,” March 8, 1981, SAPMO-BArch DY 3023/1464. Interlinkages between economic and solidarity relations were characteristic of the East German interactions with "newly independent nation states" beyond Angola as well. One prominent example is the coal plant in the Mozambican town Moatize.

42 While the JMPLA only had a few thousand members at times, the FDJ included the vast share of young GDR citizens, e. g. 2.3 million members in 1981, more than $77 \%$ of GDR citizens between 14 and 25 years of age. Unfortunately, there is hardly any secondary literature on the JMPLA; for some basic information refer to Michael Wolfers and Jane Bergerol, Angola in the Frontline (London: Zed Press, 1983). For an official historical account by the MPLA see Movimento Popular de Libertação de Angola, “História Da JMPLA,” no date, accessed November 25, 2019, http://www. mpla.ao/jmpla.39/historia.40.html.

43 Wolfers and Bergerol, Angola in the Frontline, 166; Keith Somerville, Angola: Politics, Economics, and Society (London: Pinter Publishers, 1986). 
man and Angolan sides. ${ }^{44}$ The prolonged internationalized civil war resulted in severe risks for the safety of the dispatched brigades due to which the ones in Gabela and Malanje were, for example, evacuated in $1983 .{ }^{45}$ Security concerns also co-determined the extent to which the brigades isolated themselves or engaged with the partners and society surrounding them, underlining the impression of limited and finite moorings with the possibility of sudden departure. Nonetheless, the deployment of Brigaden was continued until 1989.

\section{The Structured Practice of Solidarity in the GDR Collective}

The five Brigadetagebücher analyzed here ${ }^{46}$ were authored by four different brigades and jointly cover a time period from 1982 to 1986. These “diaries” were produced by the brigades themselves over the course of their deployment. Supposed to "represent the interesting life of the collective," 47 the diaries included written texts as well as various forms of illustrations ${ }^{48}$ from multiple authors and were part of wider documentation obligations. ${ }^{49}$ They gave "calendar sheet” reports reflecting the cycles of deployment and others on political meet-

44 Alexander Schalck to Günter Mittag, "Bericht über die Reise der Genossen Stritzke und Büttner nach Luanda/VR Angola,” November 29, 1977, Eberhard Feister to Paul Markowski, October 30, 1977, SAPMO-BArch, DY 3023/1463.

45 "Basiswechsel," SAPMO-BArch, DY 24/20215. In Mozambique, which had also officially embarked on a socialist path in 1977, rebels of the Western-financed Resistência Nacional Moçambicana (RENAMO) killed eight agricultural specialists from the GDR in 1984. See Bahr in this volume.

46 The archive Stiftung Archiv der Parteien und Massenorganisationen der DDR im Bundesarchiv (SAPMO) holds a number of these "brigade diaries" (SAPMO-BArch/DY 24). It remains unclear where other diaries may be found. The respective titles are: "Brigadetagebücher der Ernte und Reperaturbrigaden 'Comandante Bula' in Samba Caju und N' Dalatando, Angola, 1983-1984,” SAPMO-BArch, DY 24/19129; "Brigadetagebuch der Brigade 'Daniel Dangereux' in Uige, Angola, 1982-1983," SAPMO-BArch, DY 24/20213; “Brigadetagebuch der Brigade der Freundschaft in Gabela, Angola, 1983," SAPMO-BArch, DY 24/20215; "Brigadetagebuch der Brigade "Comandante Kassange” in Lobito, Angola, 1985-1986,” SAPMO-BArch, DY 24/20214.

47 "Daniel Dangereux," SAPMO-BArch, DY 24/20213.

48 While my analysis focuses on the writings of the Brigadisten, these illustrations-including clippings from publications, drawings, and photos-often assembled into collages, would be compelling sources in their own right. For an analysis of private photographs taken by East Germans during their stays abroad in the 1980s in Mozambique, consult Bahr's contribution in this volume.

49 See Harisch and Burton, "Sozialistische Globalisierung." 
ings or the fulfillment of work requirements, but also covered the extraordinary events of brigade life. These events included festivities and get-togethers with the members of the JMPLA or other "internationalists," but also recreational activities. Moreover, there was space for reflections of individual brigade members on their personal situation within the brigade collective. Taken together, the "diaries" feature relatively unguided and sometimes quite personal contents and perspectives-diverse takes on brigade life with strong individual emphases-next to more official takes on conventional markers of socialist life in the collective abroad.

The diaries represent the collectives' activities as tightly structured around the political space of the GDR and official encounters with the Angolan side confirming their mission of solidarity and mutual friendship. Reflective of their continuing close integration into the GDR's socio-political structures were the brigades' participation in work competitions for honorary titles, ${ }^{50}$ but also their duties to present solidarity donations to beneficiaries in Angola. ${ }^{51}$ Here, the brigades acted as representatives of East German organizations and companies that usually exercised their solidarity through collections from afar. ${ }^{52}$ Reports on the occasion of national political events in the GDR or certain initiatives of the Free German Youth (FDJ)-for example by transplanting “peace marches” to Angolafurther underlined how East German political rituals were perpetuated in the social life of the Freundschaftsbrigaden:

It wasn't that easy to explain without an interpreter why we should take to the streets together and that peace marches took place everywhere in the world and that the youth of the GDR also demonstrated at the same hour for the same goals. [...] Everyone of us was a little proud that we had succeeded in getting the people out of their huts and houses according to the peace contingent of the FDJ. ${ }^{53}$

50 "Öffentliche Veranstaltung zur Antragstellung zur Auszeichnung mit dem Ehrentitel 'Kollektiv der Sozialistischen Arbeit'," SAPMO-BArch, DY 24/20215.

51 "Unsere Patenklasse und die Solidarität," SAPMO-BArch, DY 24/19129; "Solidaritätsgüter aus der DDR für die Waisenkinder von 'Kipuco',” SAPMO-BArch, DY 24/20215.

52 "VEB Kraftwerkskombinat Dresden - Liebe Jugendfreunde!,” March 21, 1983, SAPMO-BArch, DY 24/20213.

53 "Es war nicht ganz einfach, ohne Dolmetscherin zu erklären, weshalb wir gemeinsam auf die Straße gehen wollten und daß Friedensmärsche überall in der Welt stattfinden und auch die Jugend der DDR zur gleichen Stunde, für die gleichen Ziele wie hier, demonstriert. ... Jeder von uns war ein bißchen stolz darauf, daß es uns gelungen war, entsprechend dem 'Friedensaufgebot der FDJ' die Menschen aus den Hütten und Häusern zu holen.” “'Keine Atomwaffen für Südafrika!' Sofortige Beendigung des unerklärten Krieges gegen die VR Angola!...,” SAPMO-BArch, DY 24/ 20215. 
Importantly, the actual work of the brigades was not necessarily linked to these reports. The political axioms in the diaries therefore often only served as general confirmations of the GDR's official political causes, extended and copied into a new environment. ${ }^{54}$ These rituals gave limited opportunity for exchange: the "peace march" was, for example, aimed against US and South African aggression as an immediate concern through which the Brigaden attested to the urgency of the GDR's anti-imperialist mission in Angola and beyond. However, while the brigades sought to mobilize the Angolan population and partners, the extension of such rituals "according to the FDJ" did not envisage their creative transformation through exchange. These rituals seem as attempts to create socialist encounters and confirm the different partners of their entangled political realities. However, the challenges to their translation and adaption rather underline how they ultimately remained rooted in the East German political space and detached from their surroundings.

The diaries further give account of a dense network of socialist encounters with other internationalists from socialist countries, representatives of the MPLA, and local leaders of the Angolan military, economy or state to strengthen the internationalist friendship. ${ }^{55}$ Delegations of the brigades were constantly invited to central political events, such as the oath-taking of Angolan soldiers, ${ }^{56}$ to which the Germans contributed short messages reaffirming their internationalist mission. ${ }^{57}$ The reports on such encounters, just as well as the ones on interlinkages with the GDR, were rife with the parlance and set phrases of solidarity as a "class duty." 58

These encounters were completed by the cooperation between the brigades of the FDJ and representatives of the party youth organization JMPLA as their official counterparts. ${ }^{59}$ Purged, and kept under strict control by the MPLA after the JMPLA's implication in the attempted coup by a disillusioned faction of the MPLA against its leadership in 1977, the JMPLA only had around 4,000 members

54 “Abzeichenprüfung für gutes Wissen," SAPMO-BArch, DY 24/20215.

55 "Marx-Gedenken bei unseren Freunden der FAPLA"; "Zu Gast bei unseren kubanischen Freunden," SAPMO-BArch, DY 24/20215.

56 "Vereidigung bei der FAPLA," SAPMO-BArch, DY 24/19129; "Vereidigung der Kämpfer der ODP," SAPMO-BArch, DY 24/20215.

57 "FDJ - Freundschaftsbrigade - Basis Gabela An das Sekretariat des Kreiskomitees von Amboim der JMPLA-JdP Gabela,” SAPMO-BArch, DY 24/20215; “Grussadresse,” SAPMO-BArch, DY 24/19129.

58 "FDJ-Freundschaftsbrigade - Basis Gabela An das Sekretariat des Kreiskomitees," SAPMOBArch, DY 24/20215.

59 Unfortunately, there is hardly any literature on the JMPLA and it proved impossible to retrieve perspectives of (former) JMPLA functionaries in contact with the brigades. 
after "rectification." It was a small cadre organization with limited pervasion in the Angolan society. ${ }^{60}$ The MPLA also identified serious deficiencies in the JMPLA with regards to its level of activity, politicization, and social responsibilities towards the country's youth. ${ }^{61}$ Documents by the FDJ's central committee show that it understood its relations to the JMPLA as privileged, but was also staunchly critical of "parasitic tendencies" within the JMPLA. ${ }^{62}$ The FDJ and JMPLA agreed that the brigades were supposed to contribute to the political profile of the JMPLA and support its development into a mass organization. ${ }^{63}$ The FDJ offered material support to the JMPLA, inter alia by printing brochures. The brigades themselves joined through work services, for example by setting up a JMPLA youth club in premises that had been "in colonial times a night club, called To the Black Diamond." 64

The Brigaden were further integrated into political cooperation by the leadership of both youth organizations as they were expected to offer political training to JMPLA functionaries. Together with the local JMPLA, the Brigaden therefore drafted working programs and held joint political forums or information events on various East German political customs or events. ${ }^{65}$ The JMPLA chapters respectively celebrated important Angolan political occasions with the brigades. Representatives of the JMPLA served the Brigaden as gate keepers and intermediaries to the political reality of Angola and accompanied them on excursions to Angolan companies or the remote rural area. ${ }^{66}$

The official encounters between members of the FDJ and the Angolan youth of the JMPLA were not limited to Angola. Five places at the Wilhelm Pieck academy of the FDJ in Bogensee were reserved for JMPLA members throughout the

60 Somerville, Angola, 92-94.

61 Somerville, Angola, 90-91.

62 "Information über den Aufenthalt einer Delegation des Zentralrates der FDJ in der VR Angola vom 25.10. -2.11.1989," SAPMO-BArch, DY 24/14424.

63 "Vereinbarung über Freundschaft und Zusammenarbeit zwischen der Freien Deutschen Jugend (FDJ) und der JMPLA - Jugend der Partei für die Jahre 1980-1982,” SAPMO-BArch, DY $24 / 22466$.

64 “Eine schöne Aufgabe. Jugendclub der JMPLA “Ché-Guevarra,”' SAPMO-BArch, DY 24/20213. 65 "Forum mit JMPLA-FDJ Freundschaftsbrigade 'Kommandante Kassange' und der Besatzung der MS 'Inselsee'," “Vorbereitung des 40. Jahrestages der FDJ,” SAPMO-BArch, DY 24/20214. 66 Besichtigung des Radio- und Fernsehwerkes von Lobito,” SAPMO-BArch, DY 24/20214; "Ein Lepradorf- Quitunga," SAPMO-BArch, DY 24/19129. Considering the limited exposure of brigade members to their Angolan environment, the brigades were in dire need of guides. To give an example, a brigade got into trouble on an unaccompanied excursion as they had unknowingly (and uncaringly) cut down a banana tree ignorant of a local farmer's ownership. "“Frühschoppen oder Organisieren’ Von Bananen im Botanischen!” SAPMO-BArch, DY 24/19129. 
1980s and a permanent representative of the JMPLA supervised young Angolans studying and working in the GDR in the second half of the 1980s. ${ }^{67}$ Furthermore, information, formalized greetings, and delegations were exchanged steadily. In March 1980, a JMPLA delegation visited Ludwigsfelde where the IFA W50 trucks exported to Angola were manufactured. Extending a practice known from Angola and interlinking their respective activities, a local youth brigade in the factory was awarded the honorary title "Dr. Agostinho Neto" to celebrate their contribution. ${ }^{68}$

In fact, the most significant recurring moment of the mutual confirmation of solidarity within Angola was the annual bestowal of the brigade's honorary title, the name of an Angolan "martyr" to the "revolution," awarded by the Angolan side. ${ }^{69}$ Names like "Daniel Dangereux," a member of the FAPLA general staff who had been killed during the attempted coup in May $1977,{ }^{70}$ signified that the Angolan army and the German brigades were leading one unified struggle. This subtly confirmed the assumed intrinsic links between everyday acts, such as the maintenance of W50 trucks, and the global cause of anti-imperialism. In its struggle for the honorary title, the friendship brigade "Comandante Bula," also named after a victim of the coup, accordingly argued: "His name is honor and obligation to us. [...] But the disputes continue. [...] The support which we can offer to the country [of Angola], is to guarantee the operability of the agrarian technology in our province."71

The internationalist role of the brigades was further reflected by the diaries in the frequent exchanges with Soviet, Bulgarian, or Vietnamese personnel next to the dominating Cuban presence. ${ }^{72}$ The collectives of internationalists shared

67 "Information über den Aufenthalt einer Delegation des Zentralrates der FDJ in der VR Angola vom 25.10. -2.11.1989," SAPMO-BArch, DY 24/14424”. For a contribution on Angolan students in the GDR see Marcia C. Schenck, "Negotiating the German Democratic Republic: Angolan Student Migration During the Cold War, 1976-90," Africa 89 (2019).

68 "Jugenddelegation bei Automobilwerken," Neues Deutschland, March 8, 1980, 2.

69 "HOJI YA HENDA - Der 14. April”; "Hoji Ya Henda würdige Verteidigung des Ehrennamens," SAPMO-BArch, DY 24/20215.

70 Paul Fauvet, "Angola: the Rise and Fall of Nito Alves," Review of African Political Economy 9 (1977): 101. An Angolan student association was named after "Commandante Dangereux" as well.

71 "Dieser Name ist für uns Ehre und Verpflichtung zugleich. [...] Aber die Auseinandersetzungen gehen weiter. [...] Die Unterstützung die wir dem Land geeben können, ist die Gewährleistung der landwirtschaftlichen Technik in unserer Provinz." "Kampf um Ehrentitel," SAPMOBArch, DY 24/19129.

72 Concerning the Cuban presence see Gleijeses, Visions of Freedom. 
extensive social contacts of friendly visits or good-spirited sports competitions, ${ }^{73}$ for example marking the International Worker's Day as a globalized event now also linked to anti-colonialist causes. ${ }^{74}$ Beyond these official expressions of friendship with Angolans and internationalists emphasizing a common sense of mission, ${ }^{75}$ the brigade diaries also occasionally mentioned more "spontaneous" and "surprising" get-togethers, implicitly giving accounts of their usually structured, mediated, and planned character: ${ }^{76}$ "On the eve of January 22, where actually nothing special was going on, ten youth friends of the JMPLA suddenly came to us [...]. They brought tapes with Angolan music with them and asked us to the play those for them as they didn't have a cassette deck. [...] For us it was interesting as well to get to know the Angolan folk, Schlager pop songs and rock music for once.”

These types of diary entries always referred to the brigade as a whole, while individual members only featured as representatives of a larger collective and its common struggle. This was because of fundamental collectivist orientations in GDR society, ${ }^{77}$ but also due to their nature as collectively produced sources for the perusal of a limited public. This collectivist rather than individualized framing, with its most direct expression in the almost exclusive use of "we" throughout the respective articles, was reinforced by the fact that the brigade members spent their free time mostly together due to constantly bemoaned language barrier as well as concerns of political control among the GDR authorities and security risks. ${ }^{78}$

At the same time, the sources omit mentioning more informal encounters between the brigade members and the Angolan counterparts or other internation-

73 “Eine schöne Aufgabe - Jugendklub der JMPLA “Ché-Guevarra,”” SAPMO-BArch DY 24/20213; "Unser Klubleben," SAPMO-BArch DY 24/20213; “Cabambe - Hier treffen sich Freunde," SAPMOBArch, DY 24/19129; "Protest,” SAPMO-BArch, DY 24/20215.

74 "1. Mai 1983 in Sumbe," SAPMO-BArch, DY 24/20215; “66. Jahrestag der Oktoberrevolution 1917," SAPMO-BArch, DY 24/19129.

75 "KAMPFPROGRAMM zur Führung des sozialistischen Wettbewerbs der FDJ-Freundschaftsbrigade Lobito im 9. Einsatzjahr 1985/86 in der VR Angola,” SAPMO-BArch, DY 24/20214.

76 "Am Abend des 22. Januar, wo eigentlich nichts besonderes los war, kamen plötzlich 10 Jugendfreunde der JMPLA zu uns [...]. Sie brachten einige Kassetten mit angolanischer Musik mit und baten uns, diese für sie abzuspielen, da sie kein Kassettengerät hätten. [...] Es war auch für uns interessant mal die angolanische Volksmusik, Schlager und Rockmusik kennen zu lernen.” Schlager is a sub-genre of German popular music, dealing with romantic themes and often delving into exoticism. "Ein unerwartet schöner Abend," SAPMO-BArch, DY 24/20123.

77 See Thomas Reichel, 'Sozialistisch arbeiten, lernen und leben': die Brigadebewegung in der DDR (1959-1989) (Köln: Böhlau, 2011), 287-294; Mählert and Stephan, Blaue Hemden, 213-216. 78 Harisch, "East German Friendship Brigades." 
alists beyond the recourse to official socialist group encounters. The Angolan addressees of East German solidarity mostly appeared in the diaries as willing apprentices of East German skills in the workplace and political activists in socialist organizations. Apart from the bestowal of individual honorary titles, namely for the "best Angolan colleagues" of the month, the Angolan contacts were subsumed under amorphous abbreviations and collective descriptions such as "the JMPLA," “Angolan friends," or just as “Angolans."

Given that unofficial contacts, not to speak of intimate relationships, were discouraged by the SED functionaries who ran the operational command in Luanda, and probably the brigade leaders in each brigade as well, they would not have been included in the Tagebücher. This lack of reports on individual encounters underlines the impression of the tight rigidity of the Brigaden's officially acceptable (inter)actions. Entries on festivities to official occasions do, however, often hint to more informal possibilities "to cement the friendship" usually during or after banquets. ${ }^{79}$

\section{The Exercise of Solidarity: Seeing like a Brigadist}

The reports in the diaries presented in the chapter above reflected the brigade collectives' mission of "enacting solidarity": ${ }^{80}$ the diaries immediately connected work duties with the struggle of the MPLA for a socialist society in the official affirmative reports of solidarity. However, the reports written from a stronger personal perspective in the focus of this chapter went beyond the officialized solidarity discourse-and possibly cliché. While the section above was seeing with us like an East German state, ${ }^{81}$ this one seeks to source the visions of solidarity of individual Brigadisten.

The Brigadisten themselves still dedicated the most space and reflection on their daily work and its impact, which stressed a practical interpretation of the brigades' presence. The Brigadisten frequently identified material shortages or technical difficulties as the ultimate challenges to "modernization" in Angola. ${ }^{82}$

79 “Zweiter Sanza Pombo Report," SAPMO-BArch, DY 24/20213.

80 "Es lebe der proletarische Internationalismus! Es lebe unsere Freundschaft!" SAPMO-BArch, DY 24/19129.

81 James C. Scott, Seeing like a State: How Certain Schemes to Improve the Human Condition Have Failed (New Haven: Yale University Press, 1998).

82 "Meine Arbeit in der Küche!," SAPMO-BArch, DY 24/20213. 
This reflects a rather technocratic understanding of their contribution as well as the fact that such language could serve as a safeguard against the shallows of political phrasing. In this context, the brigade members sought to stimulate technical innovations by giving Neuerervorschläge, "innovation proposals" common in the GDR, to overcome specific technical problems. ${ }^{83}$ The so-called "innovators' movement” (Neuererbewegung), as an official GDR policy and means to get extra payments for successful innovations, ${ }^{84}$ aimed at promoting individual initiatives to increase economic productivity. Transplanting this "movement" to Angola was an attempt to export characteristic means of East German work organization. ${ }^{85}$ The innovation proposals documented in the diaries reflected understandings of standardized and regularized work organization and the assumed possibility to directly transfer them to war-torn Angola as well. ${ }^{86}$

As such work processes were described in great detail throughout the diaries ${ }^{87}$ the Germans perceived "creativity" and "ingenuity" as their most important qualities: their individual initiative and readiness to take inconvenient steps were presented as indispensable assets within the Angolan context. The Brigadisten understood this set of skills and qualities as honed in the GDR in response to material shortages and technological deficiencies. They assumed that they could make use of these skills in the Angolan economy, in their view characterized by similar problems. Both the assumption of ingenuity as a typical East German skill as well as the link drawn between the economic conditions illustrate how the experiences in Angola illuminated the own background of the Brigadisten to them and how they deduced their role in Angola from it.

Through their day-to-day work in the car workshops, repair missions for coffee harvesting machines, and in vocational training, the Brigadisten were sure to not only achieve tangible economic progress but also directly impact their Angolan partners: "Our work did not only have statistical value but had an absolutely

83 "Bericht über die Verwirklichung des Neuerervorschlages 'Wie kann unser Waschautomat ständig und zu jeder Zeit genutzt werden,” SAPMO-BArch, DY 24/20123; "Ein Vorschlag zum Neuererwesen," SAPMO-BArch, DY 24/20215.

84 FDGB-Lexikon, s.v. "Neuererbewegung," Berlin 2009, accessed August 8, 2020, http://library. fes.de/FDGB-Lexikon/texte/sachteil/n/Neuererbewegung.html.

85 Inge Tvedten, Angola: Struggle for Peace and Reconstruction (Boulder: Westview, 1997), 70 -77; see also M. R. Bhagavan, "Establishing the Conditions for Socialism: The Case of Angola," in Africa: Problems in the Transition to Socialism, ed. Barry Munslow (London: Zed, 1986). 86 "Packen wir es an es gibt viel zu tun," "Einige Gedanken zu den Ergebnissen unserer Zusammenarbeit mit Enama; Unsere Werkstatt," SAPMO-BArch, DY 24/20123.

87 "Die Kaffeeschälanlage in Puri,” “Aktion Sanza Bombo vom 19. -22.9.1982,” SAPMO-BArch, DY 24/20123. 
real effect for our Angolan friends." 88 In this context, the brigade members understood themselves as irreplaceable mentors: "Who but us could attend to that work?"89 Thereby, the East Germans positioned themselves as "benefactor" of the Angolans, since the former presented themselves as the bearers of further progressed knowledge to be passed on to the Angolan colleagues. The aim was for the Angolans to pick up the East German dedication to work to "raise the individual responsibility and interest in participation," as one Brigadist described the mission. ${ }^{90}$ The Angolan co-workers were generally assumed to be willing learners, but still lacking these necessary qualities so that "responsibilities [could] only slowly be transferred." 91 In this way the Brigadisten also legitimized their continued presence. The Brigadisten's focus on the dissemination of knowledge and their positioning as educators of the Angolans highlights the projection of inequality and hierarchization in supposedly horizontal solidarity relations. ${ }^{92}$

The focus on practical work, still communicated within the collective as common and shared experiences, was supplemented by broader reflections of the individual Brigadisten on their own "African adventure," 93 as it was an extraordinary privilege for GDR citizens to travel overseas. ${ }^{94}$ The exoticist expectations of Brigadisten ${ }^{95}$ reporting on their first day in Angola were, however, reliably curbed by impressions of dirt, the staggeringly frequent mention of which speaks to the anticipation of an unspoiled "Africa" (but possibly also of their lacking prep-

88 “Zweiter Sanza Pombo Report," SAPMO-BArch, DY 24/20213.

89 "Zweiter Sanza Pombo Report," SAPMO-BArch, DY 24/20213.

90 "Einige Gedanken zu den Ergebnissen unserer Zusammenarbeit mit Enama," SAPMO-BArch, DY 24/20123.

91 "Unsere Werkstatt," SAPMO-BArch, DY 24/20123.

92 To a large extent, the idea of international solidarity in the GDR was based on the assumption of a shared opposition between East Germans and their partners in solidarity against global forces, such as imperialism. From this perspective, the hierarchized understanding of solidarity seems ill-fitting. On the other hand, solidarity has been described as a contradictory concept, which could also include the connection to a group perceived as different, or in need, finding an expression in humanitarian action. While not represented to a large extent in the GDR's solidarity discourse, the perspectives of the Brigadisten rather have their roots in the latter form. See Kurt Bayertz, Solidarität: Begriff und Problem (Frankfurt: Suhrkamp, 1998), 49.

93 "Meine Einreise in die VR Angola und die Fahrt nach Uíge," SAPMO-BArch, DY 24/20213. 94 "Aus dem täglichen Leben der FDJ-Freundschaftsbrigade Gabela," SAPMO-BArch, DY 24/ 20215; "Exkursion nach Massangano," "Erste Eindrücke,” SAPMO-BArch DY 24/19129.

95 The expectations communicated in such reports, which come close to travelogues, had been co-shaped by East German media coverage. For an analysis of the projections by a prominent East German journalist, see Bodie's contribution in this volume. 
aration or German babbittry). ${ }^{96}$ As one brigade member observed: "The capital of Angola made a very depressing impression on me, since everything was still different as I had imagined. [...] I spent three days in Luanda and slowly got used to half-finished houses, ever changing scents, and auto wrecks along the roads."97

Similarly, the misery observed among Angolans was addressed throughout the diaries, raising the awareness of "how much help this country needed to eliminate all the poverty still present."98 This writer's explicit disgust with the presence of "shoe shine boys" is telling because their service represented to him the continuation of exploitative economic structures in a post-colonial setting. As it was not possible to criticize the MPLA's nascent socialism, such continuing deficiencies were understood and presented as remnants of capitalism or neo-colonialism.

Indeed, the writers of the Brigadetagebücher often pointed to Angolan "backwardness," "ignorance," and even “darkness" in opposition to East German progress showcasing how myriad forms of hierarchical thinking were beneath the language of solidarity. ${ }^{99}$ Adopting the anti-colonial discourse common in the GDR, they located the causes of these miseries in the legacies of Portuguese colonial rule. These were discovered and discussed by the Brigadisten in reports on excursions to the splendor of churches, graveyards, or resorts of the colonial era juxtaposed with concrete impressions of hardships, for example in leprosy villages. Reassuringly, these contradictions were about to be overcome by the MPLA state with the active support of the Brigaden themselves. ${ }^{100}$

Against the backdrop of their perceptions of Angolan "backwardness," many writers in the Tagebücher expressed their own humanitarian concern and desires

96 “Anleitung in Bezug auf Sauberkeit und Hygiene," "Neu in N’Dalatando," SAPMO-BArch, DY 24/19129; The term babbittry refers to a kind of narrow-minded self-satisfaction with an unthinking attachment to middle-class values and materialism after the main character in Sinclair Lewis' novel Babbitt.

97 "Die Hauptstadt Angolas macht einen sehr deprimierenden Eindruck auf mich, weil alles noch anders war, wie ich es mir vorgestellt hatte. [...] Mit diesen Eindrücken verbrachte ich drei Tage in Luanda und gewöhnte mich langsam an halbfertige Häuser, ständig wechselnde Gerüche und Autowracks am Straßenrand.” “Erste Eindrücke,” SAPMO-BArch, DY 24/19129. Next to the here mentioned smell the unpunctuality of life in Angola was another frequently invoked negative impression.

98 "Meine Einreise in die VR Angola und die Fahrt nach Uíge," SAPMO-BArch, DY 24/20213. 99 "Meine Einreise in die VR Angola und die Fahrt nach Uíge," SAPMO-BArch, DY 24/20213; "Hospitation in der Patenklasse," SAPMO-BArch, DY 24/20214; “O.M.A. Die Teilnahme der angolanischen Frau an den Aufgaben der Revolution,” SAPMO-BArch, DY 24/20215.

100 "Hospitation in der Patenklasse," SAPMO-BArch, DY 24/20214; "Stadtrundfahrt in Luanda," SAPMO-BArch, DY 24/19129. 
to relieve Angolans from the starkest effects of poverty. The occasions of such reflections were found in the handover of donations, for example of clothes collected in the GDR, collective work services, or visits to partner classes in Angolan schools. The Brigadisten showered neighboring children, clothed them or fed them with German-style sandwiches (Stullen). ${ }^{101}$ Individual brigade members thereby set up their own "aid projects" reflective of their self-image as benefactors. This certainly attests to the potential for independent positioning among brigade members.

Despite the fact that individual Brigadisten put their own emphases in their activities, the personal reflections in the Brigadetagebücher expectedly did not criticize the politics of GDR solidarity. The Angolan partners were not directly criticized either. Their praise, for example of the "open atmosphere" in Angolan political conventions, is telling, however. It points to the opinion of individual Brigadisten that such a spirit was lacking in their own organization. ${ }^{102}$

The futility of relief as well as work efforts, ${ }^{103}$ not least due to the lack of supplies, found frequent expression in the diaries. Open dissatisfaction and doubts seemed acceptable in a context that explicitly subscribed to the pursuit of solidarity duties and their insufficient fulfillment. Brigade members, the initially quoted poet Rudi among them, often criticized the lack of spare parts. The expressions of discontent even extended to direct, collectively voiced criticism of the organizational priorities among superiors. This was the case when assigned tasks did not seem to align with the brigades' central objective and their Angolan partners' assumed main interest to maintain trucks: "One was not pleased, however, that just in the last week of our deployment [...] a part of our Brigadisten was kept from repairing the ENAMA trucks. [...] Whether this was actually necessary? On whose costs is surely beyond question-isn't it???"104

101 "1. Juni 1983," SAPMO-BArch DY 24/20215; "Kinderfest auf unserer Basis," SAPMO-BArch, DY 24/19129; see also "Aus dem täglichen Leben der FDJ-Freundschaftsbrigade Gabela," SAPMO-BArch, DY 24/20215.

102 "Gewerkschaftsversammlung mit der UNTA," SAPMO-BArch, DY 24/20215.,

103 "Gedanken zum Weltgesundheitstag am 7. April 1983," SAPMO-BArch, DY 24/20215, "Werkstattkollegen August und Manuel," SAPMO-BArch, DY 24/20215.

104 Please note the use of the German neuter pronoun in this case of collectively voiced criticism. "Nicht erfreut war man jedoch das ausgerechnet in der letzten Woche unseres Einsatzes [eine Maßnahme] einen Teil unserer Brigadisten von Reparaturen [...] fernhielt. [...] Ob das wohl nötig war? Auf wessen Kosten wohl steht außer Frage - oder???" "Kraftakt - auf wessen Kosten???” SAPMO-BArch, DY 24/20215. The Empresa Nacional e Mecanização Agricola (ENAMA), National Enterprise for the Mechanization of Agriculture, was the brigades' economic partner. 


\section{Conclusion}

The diaries reflect a variety of "socialist encounters" between the Freundschaftsbrigaden and their Angolan colleagues or political partners as well as their consequences. Within this context, this contribution has focused on the expressed subjectivities of the Brigadisten, presenting a range of perspectives originating in solidarity conceptions common in the GDR, but also emerging from their experiences on the spot in their temporary Angolan workplaces. Overall, the individual reflections of Brigadisten on their service were shaped by their emphasis on the impact of their work and on their position mediating the technologies to overcome the assumed "ignorance" of the Angolan society as well as relieving Angolans of crass expressions of misery.

The Brigadisten believed it their mission to help "modernize" a MPLA-ruled Angola along socialist lines. Regarding their work assignments, they emphasized skills and concrete techniques of management known from the GDR as solutions to be adopted and adapted in the nascent socialist economy of Angola. In their living environments, the Brigadisten were acutely unsettled by the encountered social realities of Angolan life in response to which they spontaneously took on the responsibility to provide aid, for example through concrete humanitarian action. Such relief efforts as well as the fact that the Brigadisten saw themselves as "agents of modernization" at the workplace reaffirmed hierarchical relations between the East German benefactors and their supposedly dependent beneficiaries. This stood in an uneasy relationship with the equality proclaimed as a basic principle of solidarity by the GDR's leadership, but can still be rooted within the contradictory implications of the solidarity concept. ${ }^{105}$

Schematic portrayals of their Angolan counterparts remained prevalent in the "diaries." These sources therefore are in many instances of limited use to understand the reciprocal effects of the relations; in their unilateral nature they mostly hint at certain entanglements. Moving on from this study, it would be crucial to find ways to account for the question of how African actors (re)produced, reflected, and rejected specific perspectives on solidarity relations in co-dependence and interaction with their Eastern "friends," whom they often located in the global North given their relative wealth. ${ }^{106}$

105 Bayertz, Solidarität, 49.

106 The impressions of Angolans and Mozambicans studying in the GDR are emphasized in Marcia C. Schenck, "A Chronology of Nostalgia: Memories of Former Angolan and Mozambican Worker Trainees to East Germany,” Labor History 59 (2018): 1. 
Still, despite their imbalances and limitations in portraying African actors and dynamics of entanglements, the sources give a clear indication of the positioning of the East German Brigadisten. The image of the Angolan realities presented in the diaries positively reflected on the GDR through the lens of solidarity. The service in Angola had the potential to stabilize the East German order in the minds of Brigadisten since Angolan misery proved to them how much material progress had already been achieved in the GDR, for example in the social sector: "Our life and our work in a developing country is instructive to us all and fills us with gratitude and recognition of our socialist health care and its achievements.”107

Yet, the brigade members did not present themselves as actors in a pressing ideological confrontation-although correspondent reflections on anti-colonialism and anti-imperialism would have seemed self-evident concerns in the context of the internationalized civil war in Angola. Whereas Toni Weis identifies a "politics machine" at work in the GDR's solidarity discourse and practices, the diary entries of the Brigadisten do not transmit an explicitly "politicized" understanding or ideologized expressions of their activities, focusing on actual mechanics of aid instead. The GDR leadership's official politicized statements of solidarity co-existed with the brigade members' emphasis on managing the concrete challenges to (socialist) modernization. Thereby, they established their own "working misunderstanding" within the structure of the Freundschaftsbrigaden, accommodating quite different emphases in interpretations of the GDR's role in Angola, even if both were within the scope of international solidarity at large.

The brigade members' assumed role as agents of modernization partly confirms Westad's emphasis on interventions in the name of modernization as a useful frame for the interpretation of the global Cold War. The diaries do, however, challenge Westad's focus on pronouncedly ideological, that is explicitly political, interpretations of such modernization and, by consequence, diminish the importance of competition with its capitalist or imperialist variation for the case of the Brigadisten. Although it was a self-evident opportunity to fill the space of the "diaries" with cliché phrases of anti-imperialism, the Brigadisten did not engage in political rhetoric. ${ }^{108}$ Rather, their writing highlights the impact of a "de-

107 "Unser Leben und unsere Arbeit in einem Entwicklungsland ist für uns alle sehr lehrreich u. erfüllt uns mit Dank u. Anerkennung für unser sozialistisches Gesundheitswesen und seine Errungenschaften." "Gedanken zum Weltgesundheitstag am 7. April 1983," SAPMO-BArch, DY 24/20215; “Tag des Gesundheitswesens,” SAPMO-BArch, DY 24/19129.

108 While it is certainly hardly possible to interpret 'modernization' with its baked-in teleology and aspirations in non-ideological terms and thereby extract ideology from it, my argument is 
velopmentalist paradigm" understood as a "humanitarian mission of modernization" as the guiding interpretation of their experiences in the postcolonial world. ${ }^{109}$ In this spirit, the brigade poet Rudi concluded the typical brigade member's accomplishments relating to their perceived modernizing as well as humanitarian mission to the occasion of their "disentanglement," their heaving out:

Du lerntest wahre Not erkennen, warst stets bereit Dich zu bekennen.

Tratst ein für Fortschritt und Verstand, und gabst dein Wissen unverwandt.

You came to see real distress, you were ever ready to profess. You stood up for progress and reason. and steadfastly, you gave your ken. ${ }^{110}$

\section{Bibliography}

Bayertz, Kurt. Solidarität: Begriff und Problem. Frankfurt: Suhrkamp, 1998.

Bergerol, Jane, and Michael Wolfers. Angola in the Frontline. London: Zed Press, 1983.

Bhagavan, M. R. "Establishing the Conditions for Socialism: The Case of Angola." In Africa:

Problems in the Transition to Socialism, edited by Barry Munslow. London: Zed, 1986.

Birmingham, David. "Angola." In A History of Postcolonial Lusophone Africa, edited by Patrick Chabal, 137-185. London: Hurst, 2002.

Brock, Lothar, and Hans-Joachim Spanger. Die beiden deutschen Staaten in der Dritten Welt:

Die Entwicklungspolitik der DDR - eine Herausforderung für die Bundesrepublik

Deutschland? Opladen: Westdeutscher Verlag, 1987.

Burton, Eric. "Solidarität und ihre Grenzen: Die Brigaden der Freundschaft der DDR." In Internationale Solidarität: Globales Engagement in der Bundesrepublik und der DDR, edited by Frank Bösch, Caroline Moine, and Stefanie Senger, 152-185. Göttingen: Wallstein Verlag, 2018.

Büschel, Hubertus. Hilfe zur Selbsthilfe: Deutsche Entwicklungsarbeit in Afrika 1960-1975. Frankfurt: Campus, 2014.

Cooper, Frederick. Colonialism in Question: Theory, Knowledge, History. Berkeley: University of California Press, 2005.

Engerman, David. "Development Politics and the Cold War." Diplomatic History 41 (2017): 1-19.

that the expressly ideological conflict of the Cold War played a diminished role in this case. For the relevant take on modernization, please see Cooper, Colonialism in Question, 113-149.

109 For the establishment of this paradigm see Katrina M. Hagen, "Internationalism in Cold War Germany,” (Ph.D. diss., University of Washington, 2008), 42.

110 “Abschied von N'dalantando!” SAPMO-BArch, DY 24/19129. 
Fauvet, Paul. "Angola: The Rise and Fall of Nito Alves." Review of African Political Economy 4 (1977): $88-104$.

FDGB-Lexikon. s.v. “Neuererbewegung.” Berlin 2009. Accessed August 8, 2020. http://library. fes.de/FDGB-Lexikon/texte/sachteil/n/Neuererbewegung.html.

“Franke." "Mein Angola 1984." Angola Forum. Accessed January 21, 2020. http://www.angolaforum.de/thread.php?board=3\&thread=1.

Gleijeses, Piero. Visions of Freedom: Havana, Washington, Pretoria and the Struggle for Southern Africa, 1976-1991. Chapel Hill: University of North Carolina Press, 2016.

Gödeke, Ulrike. "Zwischen brüderlicher Hilfe und allseitiger Stärkung der DDR: Die Freundschaftsbrigaden der FDJ in Afrika 1964 bis 1990.” Diploma thesis, Freie Unversität Berlin, 2002.

Hagen, Katrina M. “Internationalism in Cold War Germany." Ph.D. dissertation, University of Washington, 2008.

Harisch, Immanuel R. "Bartering Coffee, Cocoa and W50 Trucks: The Trade Relationships of the GDR, Angola and São Tomé in a Comparative Perspective." Global Histories 3 (2017): 43-59.

Harisch, Immanuel R. "Handel und Solidarität: Die Beziehungen der DDR mit Angola und São Tomé und Príncipe unter besonderer Berücksichtigung des Austauschs 'Ware-gegen-Ware' ca. 1975-1990.” Master's thesis, Universität Wien, 2018.

Harisch, Immanuel R. "East German Friendship-Brigades and Specialists in Angola: A Socialist Globalization Project in the Global Cold War." In Transregional Connections in the History of East Central Europe, edited by Katja Naumann. Berlin: de Gruyter, forthcoming 2021.

Harisch, Immanuel R., and Eric Burton. "Alltagszeugnisse sozialistischer Globalisierung: Die Tagebücher der DDR-Freundschaftsbrigaden.” Unpublished manuscript. Forthcoming in Zeithistorische Forschungen.

Hatzky, Christine. Cubans in Angola: South-South Cooperation and Transfer of Knowledge, 1976-1991. Madison: University of Wisconsin Press, 2015.

Lorenzini, Sara. Global Development: A Cold War History. Princeton: Princeton University Press, 2019.

Mählert, Ulrich, and Gerd-Rüdiger Stephan. Blaue Hemden - Rote Fahnen: Die Geschichte der Freien Deutschen Jugend. Opladen: Leske und Budrich, 1996.

MDR.de. “Mit einer FDJ-Freundschaftsbrigade in Angola." January 31, 2011. Accessed November 25, 2019. https://www.mdr.de/damals/archiv/artikel105354.html.

Movimento Popular de Libertação de Angola. "História Da JMPLA.” Accessed November 25, 2019. http://www.mpla.ao/jmpla.39/historia.40.html.

Reichel, Thomas. 'Sozialistisch arbeiten, lernen und leben': Die Brigadebewegung in der DDR (1959-1989). Köln: Böhlau, 2011.

Roesler, Jörg. "Berichtsbuch, Beschwerdeschrift oder Bilderfolge? Unterschiedliche Vorstellungen zum Inhalt von Brigadetagebüchern in den Anfangstagen der 'sozialistischen Kollektive."' In Vorwärts und nichts vergessen. Sprache in der DDR was war, was ist, was bleibt, edited by Ruth Reiher and Antje Baumann, 206-214. Berlin: Aufbau, 2004.

Schenck, Marcia C. "A Chronology of Nostalgia: Memories of Former Angolan and Mozambican Worker Trainees to East Germany." Labor History 59 (2018): 352-374. 
Schenck, Marcia C. "Negotiating the German Democratic Republic: Angolan Student Migration During the Cold War, 1976-90.” Africa 89 (2019): 144-166.

Schleicher, Hans-Georg. "The German Democratic Republic (GDR) in the Liberation Struggle of Southern Africa." In Southern African Liberation Struggles 1960-1994:

Contemporaneous Documents, edited by Arnold Temu and Joel das Neves Tembe. Dar es Salaam: Mkuki na Nyota, 2014.

Schleicher, Ilona. “Elemente entwicklungspolitischer Zusammenarbeit in der Tätigkeit von FDGB und FDJ." In Entwicklungspolitische Zusammenarbeit in der Bundesrepublik Deutschland und der DDR, edited by Hans-Jörg Bücking. Berlin: Duncker \& Humblot, 1998.

Scott, James C. Seeing like a State: How Certain Schemes to Improve the Human Condition Have Failed. New Haven: Yale University Press, 1998.

Shubin, Vladimir. The Hot 'Cold War': The USSR in Southern Africa. London: Pluto Press, 2008.

Somerville, Keith. Angola: Politics, Economics, and Society. London: Pinter Publishers, 1986.

Tvedten, Inge. Angola: Struggle for Peace and Reconstruction. Boulder: Westview, 1997.

Unfried, Berthold. 'Instrumente und Praktiken von 'Solidarität' Ost und 'Entwicklungshilfe' West: Blickpunkt auf das entsandte Personal." In Die eine Welt schaffen: Praktiken von 'Internationaler Solidarität' und 'Internationaler Entwicklung.', edited by Berthold Unfried and Eva Himmelstoss, 73-98. Leipzig: Akademische Verlagsanstalt, 2012.

van der Heyden, Ulrich. "FDJ-Brigaden der Freundschaft aus der DDR - die Peace Corps des Ostens?" In Die eine Welt schaffen: Praktiken von 'Internationaler Solidarität' und 'Internationaler Entwicklung.', edited by Berthold Unfried and Eva Himmelstoss, 99-122. Leipzig: Akademische Verlagsanstalt, 2012.

Weis, Toni. "The Politics Machine: On the Concept of 'Solidarity' in East German Support for SWAPO." Journal of Southern African Studies 37 (2011): 351-367.

Westad, Odd Arne. The Global Cold War: Third World Interventions and the Making of Our Times. Cambridge: Cambridge University Press, 2005.

Westad Odd Arne. "The Cold War and America's Delusion of Victory." New York Times, August 28, 2017. Accessed November 25, 2019. https://www.nytimes.com/2017/08/28/opinion/ cold-war-american-soviet-victory.html.

Witkowski, Gregory. "Between Fighters and Beggars: Socialist Philanthropy and the Imagery of Solidarity in East Germany." In Comrades of Color: East Germany in the Cold War World, edited by Quinn Slobodian, 73-95. New York: Berghahn, 2014. 